\title{
13. The domestic and the wild in the Mongolian horse and the takhi
}

\author{
Natasha Fijn
}

\section{Introduction}

Against a strong head wind we reached this almost flat plateau, at a height of 6,800 ft., and immediately saw, a few kilometers off, a group of animals galloping away from us at full speed. My Mongolian companion, Namkhajdorj Balgan, recognised them at once with the naked eye as Przewalski wild horses, and subsequent observation with a telescope confirmed beyond any possible doubt that this was what they were ... We followed them for about six or eight miles over quite open ground and observed them by telescope until they disappeared (Kaszab, 1966: 346).

The account above is by a scientist on a joint Hungarian-Mongolian expedition in the summer of 1966. This was the last published sighting of horses in the wild in the scientific literature. The final sighting of this unique horse was actually recorded in 1969 by the Mongolian scientist N. Dovchin (Bouman and Bouman, 1994). There were, no doubt, further sightings by local Mongolian herders travelling with their herds to waterholes in the area. These herding families would have had an intimate knowledge about the habits of the takhi, passed down from one generation to another over the millennia. The location, near the border between China and Mongolia, was sparsely populated and the final retreat for the last Asiatic wild horse population. Mongolian herders called this mountainous location Takhiin Shar Nuruu, which translates as The Yellow Wild Horse Mountain Range. With their knowledge of horses, Mongolian herders would have recognised the significance of this area as a refuge for the takhi.

One of the earliest written references to the takhi was in The Secret History of the Mongols where it describes how Chinggis Khan fell from his horse when it was startled by takhi (Bouman and Bouman, 1994). To Mongolians the takhi is the 'father' of the Mongolian horse. The horse is an inherent part of their identity as herders and as Mongolians. Stamina and strength are prized characteristics in a Mongolian horse and the takhi represents the epitome of these features. The intention of this paper is to re-examine the notions of domestic and wild in relation to the 'domestic' Mongolian horse and the 'wild' takhi from Mongolia, 
not just from a western perspective but also through a cross-cultural lens from living with herders and their herd animals in the Khangai Mountains of Mongolia.

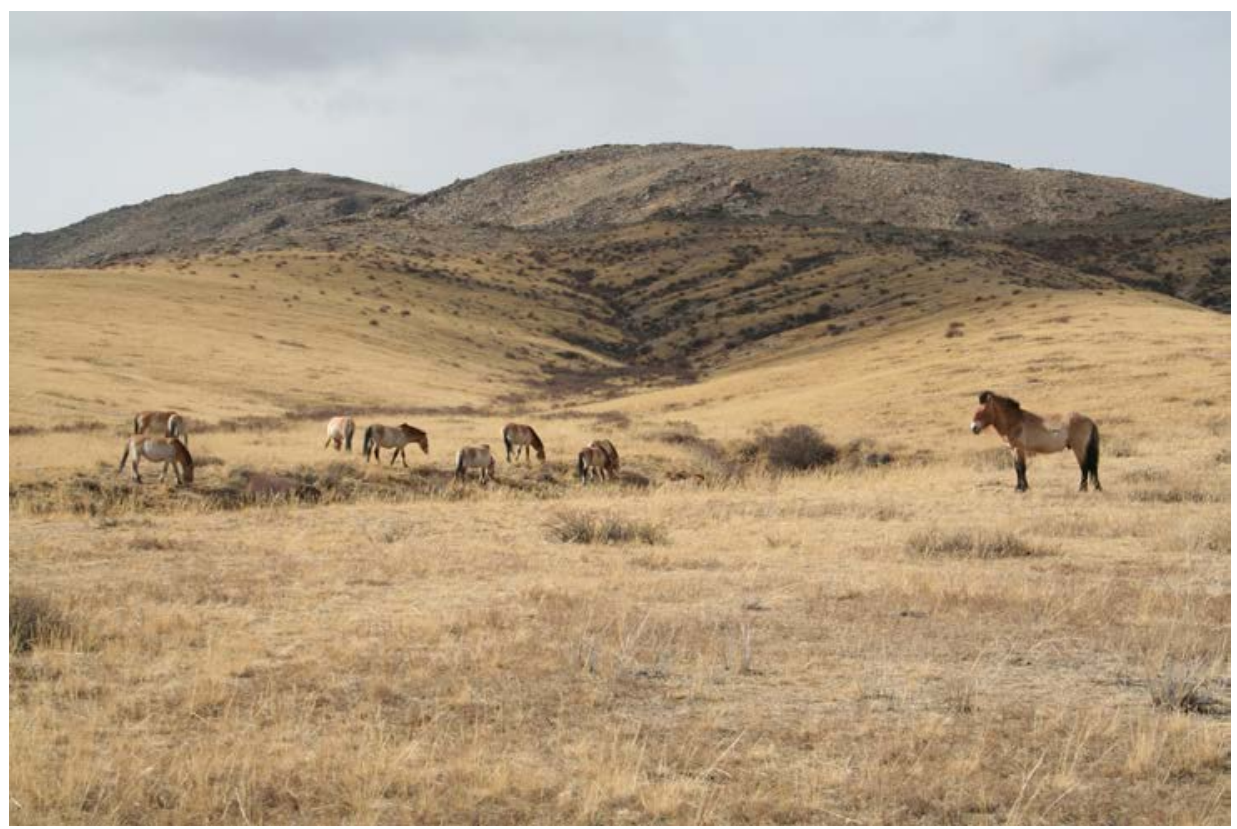

Figure 13.1: Takhi herd with stallion to the right, Hustai Nuruu National Park, 2007.

Source: Photograph by Natasha Fijn

\section{Taxonomy and morphology of wild horse characteristics}

During the Paleolithic, in both present-day France and Spain, humans were painting and etching horses on the walls of caves and making small clay horse figurines. These depictions of the wild horses they hunted bear a remarkable resemblance to the Asiatic wild horse, or Equus przewalskii. The horses had upright manes and 'beards' along the jaw line with light muzzles and underparts (see Figures 4-6 in Mohr, 1971; Figure 2 in Pruvost et al., 2011).

When Linnaeus (1707-1778) formed the classification system for scientific nomenclature, he made no mention of the Asiatic wild horse because such a horse was not yet known to exist according to the current knowledge in Europe (Bouman and Bouman, 1994). A wild horse population, Equus ferus ferus, known 
as the tarpan, was still clinging on to existence on the steppes of the Ukraine when another wild horse population was 'discovered' in 1881 (or made more widely known) through Colonel Przewalski's reports on his explorations into Central Asia. The tarpan was mouse-grey and would turn almost white in the winter to camouflage with its snowy environment. In contrast the Asiatic wild horse varied from rust or dun-coloured to bay (Groves, 1994; see Figures 13.1 and 13.2).

In 1986, Colin Groves recognised two wild horse taxa that survived into historic times, Equus ferus przewalskii Poliakov, 1881, and Equus ferus ferus Boddaert, 1785. Groves outlined key differences in external and cranial morphology between the 'wild type' Przewalski horse and that of the domestic horse from examining museum specimens, photographs, the current literature and descriptive accounts of the horse. These differences were based on a close analysis of the stature, weight, body conformation, head form, body colour, mane and tail, body hair, cranial characteristics and postcranial skeleton (described by Groves and Willoughby, 1981; Groves, 1994; Groves and Grubb, 2011).

More recently, in a revision of the taxonomy of ungulates, Groves concluded that Equus przewalskii should be recognised as distinct; that the domestic horse should retain its historic scientific name Equus caballus; while the extinct tarpan should be known in the scientific nomenclature simply as Equus ferus (Groves and Grubb, 2011). As Groves states, 'it is often convenient to refer to domestic animals by their own scientific name, regardless of the fact that they might, in fact, be of mixed (or hybrid) origin' (2011: 8).

The research by Colin Groves on the taxonomy and the morphology of Equus przewalskii and his interest in domesticated animals was one of the reasons that I began research based in Mongolia. I was initially interested in conducting cross-cultural research in Mongolia to gain a window into the domestication processes in relation to the horse. The research for my doctoral thesis broadened to encompass ethnography about multispecies hybrid communities, both human and nonhuman, including Mongolian herders, horses, cattle (including yak), sheep and goats. Throughout 2005 and during a shorter trip in the spring of 2007 I lived with Mongolian herders in two extended family encampments in the Khangai Mountains. Through daily interaction, while milking and herding, individual herders gain a remarkable knowledge about the reproduction, breeding, communication, social behaviour and ecology of these herd animals. Horses are a particularly significant part of Mongolian herding culture (see Fijn, 2011). ${ }^{1}$

1 To see footage, by the author, of the importance of the horse in relation to horse racing within a winter festival, see: http://khangaiherds.wordpress.com/about/khangai-herds-extra/. 


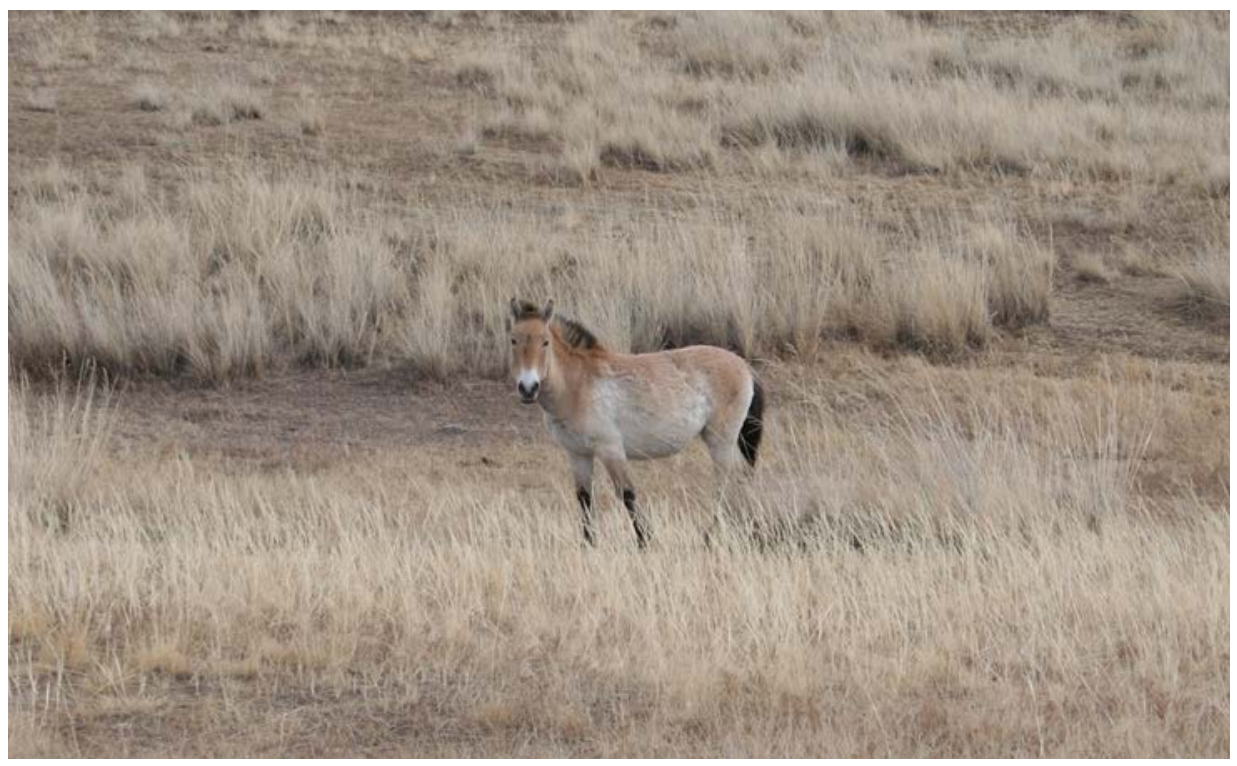

Figure 13.2: Individual takhi at Hustai Nuruu National Park, 2007.

Source: Photograph by Natasha Fijn.

Research in the field was conducted through observational filmmaking, semi-structured interviews and the anthropological technique of participant observation, living in a herding encampment with an extended herding family (which included living amongst herd animals). Within this chapter I return to what initially sparked my interest in Mongolia in the first place, the horse, and through a multidisciplinary, cross-cultural perspective I examine the relationship between the 'domestic' Mongolian horse and the 'wild' takhi (Equus przewalskii) (see Figures 13.1 and 13.2).

\section{The common name for Equus przewalskii}

Human, Mongolian horse and takhi all co-existed in the same environment. Mongolians refer to the predominant breed of horse that is native to Mongolia as Mongol and to the one that is not tamed by humans as takhi. ${ }^{2}$ Historically, Mongolians also distinguished between a darker mountain variety and a lighter steppe variety of takhi. ${ }^{3}$ Colonel Przewalsky, by contrast, mistook sighting

2 Henceforth in this paper I refer to the tame horse (Equus caballus) that co-exists with Mongolian herders as the 'Mongolian horse' and to Equus przewalskii as 'takhi'.

3 This aligns with the views of early twentieth century authors, who named and described two different geographic populations of takhi, recognising them as distinct. 
Mongolian wild asses, or khulan, for wild horses when they galloped off as a herd into the distance. It was only due to good fortune and luck that he happened to be given what became the type specimen, by Kirghiz hunters on the border between Russia and Mongolia.

Many academics working on research relating to the rehabilitation of Equus przewalskii into reserves refer to the horse by the Mongolian name of takhi. Van Dierendonck and Wallis de Vries (1996) state that they prefer the name takhi because Przewalski horse is misleading in that it should not be confused with the domestic Mongolian horse. The Mongolian term takhi recognises the status of this horse as a significant part of Mongolia's cultural heritage. Colonel Przewalski, sometimes spelt Przhevalsky or Prjevalsky, also had his name attributed to a species of gazelle and 80 different plant species. According to Meyer and Brysac, Przewalsky was a ruthless exploiter of the Central Asian peoples he encountered, travelling 'with a carbine [shotgun] in one hand, a whip in the other' (cited in Nalle, 2000: 199-200). The fact that the horse is still commonly referred to as 'Przewalski's horse' denotes a retention of a colonialist and imperialist form of ownership of both the name and the horse itself.

\section{The domestic and the wild}

There is a tendency in the western world to form Cartesian dualistic divisions between nature and culture, male and female, domestic and wild, native and feral. This stems from a historical basis in Judeo-Christian traditions and beliefs where the world is categorised and divided into good and evil, right and wrong, and continues into present-day Western knowledge systems, where this framework can inadvertently persist. This is not to say, however, that a categorisation according to domestic and wild animals should not be made. The intention within this chapter is to avoid viewing the domestic and the wild as 'hyper-separated' and instead think of them along a continuum, where there can be considerable crossover between the two forms. The environmental philosopher Val Plumwood provides a clear perspective on human/nature dualism in saying that this mindset 'conceives the human as not only superior to but as different in kind from the non-human, which as a lower sphere exists as a mere resource for the higher human one. This ideology has been functional for Western culture in enabling it to exploit nature with less constraint, but it also creates dangerous illusions by denying embeddedness in and dependency on nature' (Plumwood, 2012: 15).

Sandor Bökönyi's definition of a domestic animal is representative of earlier views of animal domestication in the following: 'The essence of domestication is the capture and taming by man of animals of a species with particular 
behavioural characteristics, their removal from their natural living area and breeding community, and their maintenance under controlled breeding conditions' (Bökönyi, 1989: 22). Juliet Clutton-Brock recently defined 'true' domestication as the 'keeping of animals in captivity by a human community that maintains total control over their breeding, organization of territory, and food supply' (Clutton-Brock, 2012: 3 emphasis added). These definitions may apply to a categorisation according to a western perspective but this does not apply to a Mongolian herding perspective, nor to the way herd animals live in Mongolia (see chapter by Clutton-Brock, this volume).

The definition is of course correct in relation to how horses are kept in a western scenario, where the territory is decided upon by humans with often only one or two horses within a grassed area bounded by fences, or indoors on their own within a stable. Many are strictly bred according to studbooks through artificial insemination. Thoroughbreds are perhaps a good example of this definition of the domestic, in terms of total human control over their breeding, territory and food supply.

The Mongolian horse is not held in captivity because the land in Mongolia is not fenced and they are free to roam without human-made barriers. They have not been removed from their natural environment, as the grassland steppe habitat was still occupied by wild horses until historic times and it is likely that their ancestors in the Pleistocene roamed over a similar grassland landscape, perhaps even in the same geographical location. Mongolian horses choose where to forage, they protect themselves from predators and even make their own way to new seasonal pastures ahead of the herding encampment. Mongolian horses exist within a social structure that they would naturally adopt, for example, the main herd generally consists of a stallion and up to 25 mares with their young. Herders do not have total control over their breeding, as a stallion can potentially impregnate mares from another herd if he can outcompete another stallion.

In contrast, for 13 generations the entire takhi population were socially disrupted, captured, removed from their natural living area by being transported from Mongolia to Europe and other parts of the world, separated into human controlled breeding communities, or zoos, and maintained under controlled living conditions. Humans had total control of their breeding and organisation of territory because not one individual remained on the grassland steppe of Mongolia. Because the population spent over 90 years in captivity, the takhi required protective enclosures before being released back into reserves

4 For an ethnography related to the breeding of thoroughbreds and horse racing, see Cassidy (2002). 
in Mongolia, as individuals had not learnt how to survive the extremely harsh Mongolian winters without supplementary feed, nor that they could be prey to wolves.

The 'domestic' Mongolian horse is not closely monitored by herders against wolf attack (see Hovens and Tungalaktuja, 2005). During the harsh winter they do not require additional feed but survive on the standing fodder that grows only during the short summer season (see Figure 13.3). When snow covers the ground, Mongolian horses know how to paw through the snow to get at the vegetation beneath. Van Dierendonck and others (1996) and Linklater (2000) found that the behaviour and social structure of the takhi, once they had been rehabilitated back onto the grassland steppe, was remarkably similar to feral horse populations. This is also the case in Mongolian 'domestic' horse herds. I observed that their social organisation was remarkably similar to findings in relation to the reintroduced takhi and to 'feral' horse populations (see Fijn, 2011: 65-69).

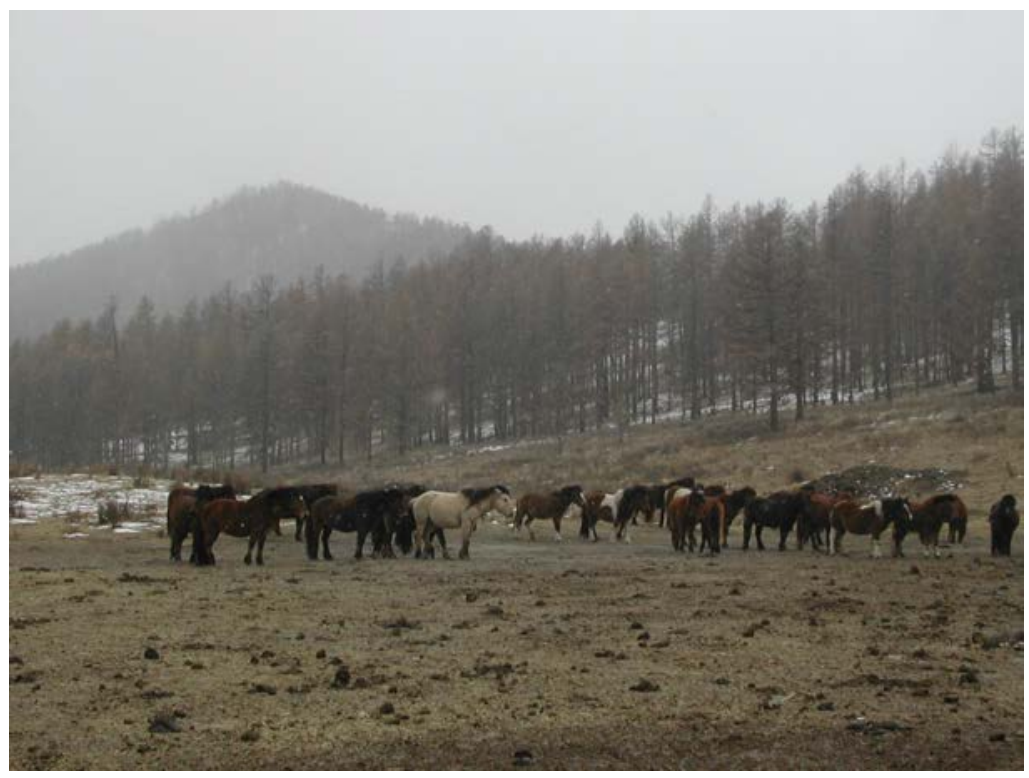

Figure 13.3: A Mongolian horse herd in a snowstorm in spring, Arkhangai Province, 2005.

Source: Photograph by Natasha Fijn.

It seems ironic that, according to the dualistic categorisation of domestic and wild, the way the 'domestic' Mongolian horse exists does not fit the criteria of a domesticated animal, whereas the 'wild' Mongolian horse living within a captive zoo fits the accepted definition of a domestic animal well. It reveals a difference 
in attitude whereby ' $[\mathrm{t}]$ he behaviour of a species is often one of the last areas of their biology to be studied and one of the last aspects to be considered in making management decisions' (Boyd and Houpt, 1994: 267); whereas for Mongolian herders the behaviour of the horse is a priority. I agree with Kaczensky and others' (2007) recommendation that local Mongolian herders need to be more actively involved in the management and conservation of the takhi, including recognising their depth of knowledge in relation to the behaviour and social structure of the horse. Through the takhi's reintroduction back into three separate reserves in Mongolia since 1992, the herds have gradually been given some of their own agency back and, hopefully, will ultimately be released from total human control and management. ${ }^{5}$

In comparison to many rangelands throughout the world, the pastoral ecosystem in Mongolia is relatively intact (see Mallon and Jiang, 2009). The herders, herd animals and their wild counterparts have all co-existed and adapted within a functioning ecosystem for thousands of years. A sign of a healthy ecosystem is if top predators still persist in the landscape and in Mongolia there are still wolves (Canis lupus) and, although endangered, other large predators, such as the Gobi bear (Ursus arctos) and snow leopard (Uncia uncia). Large ungulates still inhabit Mongolia including wild representatives that are related to the domestic animals, such as argali (Ovis ammon), ibex (Capra sibirica) and wild Bactrian camels (Camelus ferus). In many of these cases Mongolia functions as one of the last vestiges for these large mammals that during the Pleistocene would have lived in far greater numbers across large parts of Eurasia (Bedunah and Schmidt, 2000).

\section{A cross-cultural re-examination of the accounts of capturing takhi}

Cultural differences in approach to the human-horse relationship have been evident from ancient and classical history. These differences persist to the present day. There are two main approaches, a co-operative approach based upon understanding the behaviour of the horse, and an alternative approach based on human dominance and equine submission. Social interactions and contact between humans and horses have reflected these differences in approach (Van Dierendonck and Goodwin, 2005: 65).

5 There has been a large body of scientific research focusing on the behaviour and ecology of the takhi after reintroduction into reserves in Mongolia (see King, 2002; King and Gurnell, 2005, 2007; Van Dierendonck and Wallis de Vries, 1996; Van Dierendonck et al., 1996). 
This nicely summarises the difference between a historically Euro-American approach toward horses and a Mongolian herding one. In this section I draw upon my observations of how herders captured and tamed Mongolian horses and integrate these ethnographic details with earlier historic accounts to consider how the recruitment of wild individuals into a tame Mongolian horse herd could potentially occur.

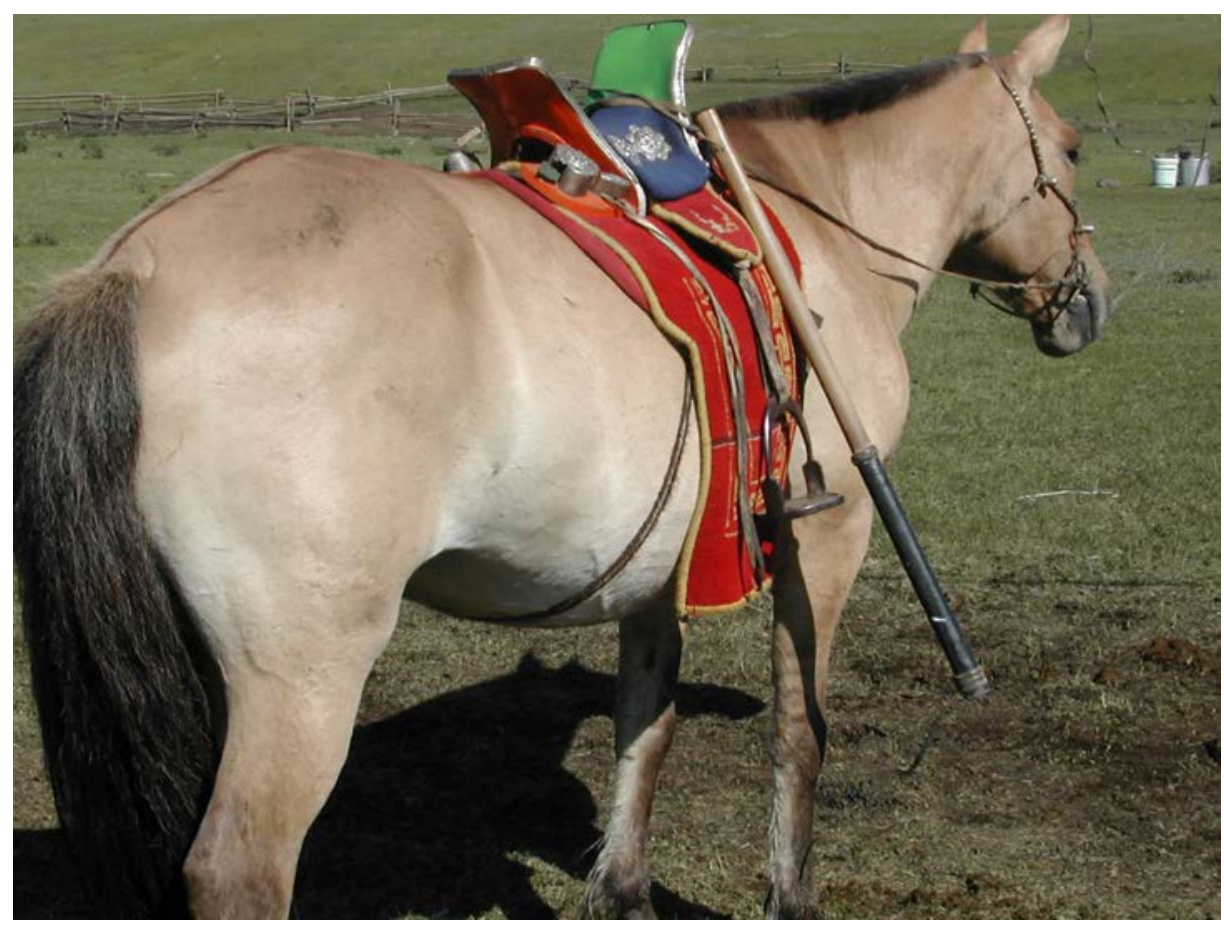

Figure 13.4: A prized Mongolian horse with elaborate saddle and bridle and wild-type characteristics, note the coat colour, stripes on the legs and eel-stripe down the back, 2005.

Source: Photograph by Natasha Fijn.

While in the field, I asked herders about their favourite horses. They were often selected on the basis of their fine appearance, distinctive markings, or quiet behaviour. One particular aspect that was particularly favoured were ancestral, or wild-type, characteristics, reminiscent of ancient cave paintings: a dun coat, dark mane and tail, dark eel-stripe down the back and faint stripes on the upper legs and neck. As early as 1868 Charles Darwin perceptively recognised these features as possible 'wild-type' characteristics in certain breeds of horse. Lusis (1943) described how the 'wild-dun colour' is common in Mongolian domestic horses and how it is always combined to some degree with striping on the legs. Bökönyi noted the resemblance of some domestic horses in Central Asia to the 
takhi, not only in the colouration of the horse but also the shape of the skull. Some Kazakh horses 'faithfully present the colour of the takhi, they have a welldeveloped dorsal stripe ... and they often have stripes on their legs' (1975: 85). From noting these characteristics in the field, I began to consider that perhaps these markings were an indication that the Mongolian horse represents an ancient breed of domestic horse and is evidence of their long association and bond with Mongolian herders; or perhaps even an indication that on rare occasions takhi may have interbred with Mongolian domestic horses and contributed to their genetic heritage (see Figure 13.4).

Bökönyi pointed out that a good motivation for herders to occasionally introduce individuals from a wild herd was to increase the number of herd animals, as the size of the herd is representative of a herding family's wealth. He states, 'even at the end of the last century and the beginning of ours it happened that Mongolian animal breeders would capture Przevalsky foals, admit them to their herds and rear them there: that is to say, they domesticated them' (1974: 85). From observing how herders in Mongolia catch foals with an urgaa, or lasso pole, I can readily envisage how individuals from a wild population could be captured. One way is through herders capturing foals by chasing the takhi herd on horseback until a foal tires, separating the foal from the herd, and then the herder could merely slip the urgaa over the exhausted foal's head. ${ }^{6}$

An account from one of the brothers Gram-Grshimailo, credited as being the first Europeans to see takhi in the wild, related such a scenario:

[T] he Mongols have often attempted to tame [adult] wild horses but always in vain. The wild horse will not accept human contact, is terrified of them and will not allow himself to be used. Wild horses are caught in a fairly simple manner. During the foaling season the Kalmucks [western Mongolians in Russia] take two horses into the desert. As soon as they have found a herd, they chase them until the exhausted foals fall over. These foals are picked up and put into the domesticated herd (quoted in Mohr, 1971: 68).

This technique does correspond with techniques still used by Mongolian herders today, as I have observed herders use a similar technique on a number of occasions by relying on exhaustion to break in their two-year-old horses. One adult herder may ride the mare (or the horse's mother), while a lighter teenager leaps onto the two-year-old bareback, inducing the young horse to buck and gallop alongside the mare until it is too exhausted to attempt to get rid of the rider and becomes calm (also see Fijn, 2011: 144-147).

6 It is general knowledge within the oral history of Mongolian herding families that the two kinds of horse readily interbred in the past. I was informed that they produced 'good stock' but that herders kept their techniques a secret (Ranger at Hustai Nuruu, pers. comm., 13 April 2005). 
Unfortunately, this technique of capturing the foals was misappropriated by European hunters to capture takhi in order to take them to zoos in Europe. The hunters were additionally instructed by Falz-Fein (a wealthy zoo owner who engaged in the business transactions with the hunters) to shoot the mares in the herd before capturing the foals. Falz-Fein was proud of this technique and wrote 'I laid much stress on the animals not being chased before capture, but rather by shooting their mother. As we could not get milking mares from the Mongolians living in the area, we had to buy them in Bijsk and have them covered so they foaled at the same time as the wild mares. In order to feed the wild foals we had to kill the tame ones' (Mohr, 1971: 95-96). Bökönyi regretted such a practice, as 'to kill the mother mares with a view to catch the foals more easily was an appalling procedure indeed ... The killing of the mares put an end to the possibility of a number of further foals being born' (1974: 98).

A Mongolian scientist, S. Dulamtseren, commented that one of the reasons for the extinction of the last population of takhi in the wild was due to the breakdown of the social structure of the herd by these hunters activities (van Dierendonck and Wallis de Vries, 1996). On just one expedition in 1901 the hunters captured 51 foals. Of these, only 28 survived the stressful journey to a European zoo (Bökönyi, 1974). This practice would have been counter to the ethics of Mongolian herders, as they do not kill female animals that are still able to reproduce.

Even though horses are generally able to roam free within their own herd in Mongolia, during the summer season foals are tethered along pegged lines, so that the herders can obtain milk from the mares. ${ }^{7}$ In the instance of the takhi foals, the herder would be able to encourage the foal to feed from a surrogate mare, just as herders do today. Often at least one mare loses her own foal to wolf predation and is encouraged to adopt another, or perhaps even two. The adopted foal is handled many times a day when it is taken to feed from the mare prior to milking and in this way the foal becomes quite tame and easily handled later in life. If a takhi foal grew up within a horse herd, nurtured by a surrogate mare, then the takhi is more likely to integrate with the herd as an adult and subsequently reproduce further (hybrid) offspring.

Bökönyi (1974) provided an archaeological example from kurgans (burial mounds) from the Turkic period in Mongolia. One of the horses sacrificed within the burial mound corresponded with the skull of an interbred horse from a takhi mare and a Mongolian stallion. It would not be a great biological leap for a takhi to breed with a Mongolian horse, as they do produce viable, fertile offspring. A greater biological distance exists between the Mongolian yak

7 To see footage by the author of a young herder catching adult horses with an urgaa, followed by foals and two-year-olds being handled during milking, see: www.khangaiherds.wordpress.com/about/khangai-herdspart-3/. 
and the Mongolian cow, yet I observed how readily they breed within a mixed herd of a yak bull (or bulls), Mongolian cows and yak-cow hybrids (see Fijn, 2011: 87-89). In summary, it is highly probable that throughout history wild horses, in this instance takhi, were on occasion integrated and bred with tame horse herds, specifically Mongolian horse herds.

Bökönyi acknowledged that the takhi may have interbred with tame Mongolian horses in the past, but this 'does not at all reduce their quality as genuine wild horses' (1974: 45) and still means that they are a unique population of horse in their own right. With the inclusion of my ethnographic observations, it is feasible that individuals could have been caught from this distinct population and integrated within the domestic horse population as foals, ultimately contributing to the genetic heritage of the domestic Mongolian horse (see Figure 13.5).

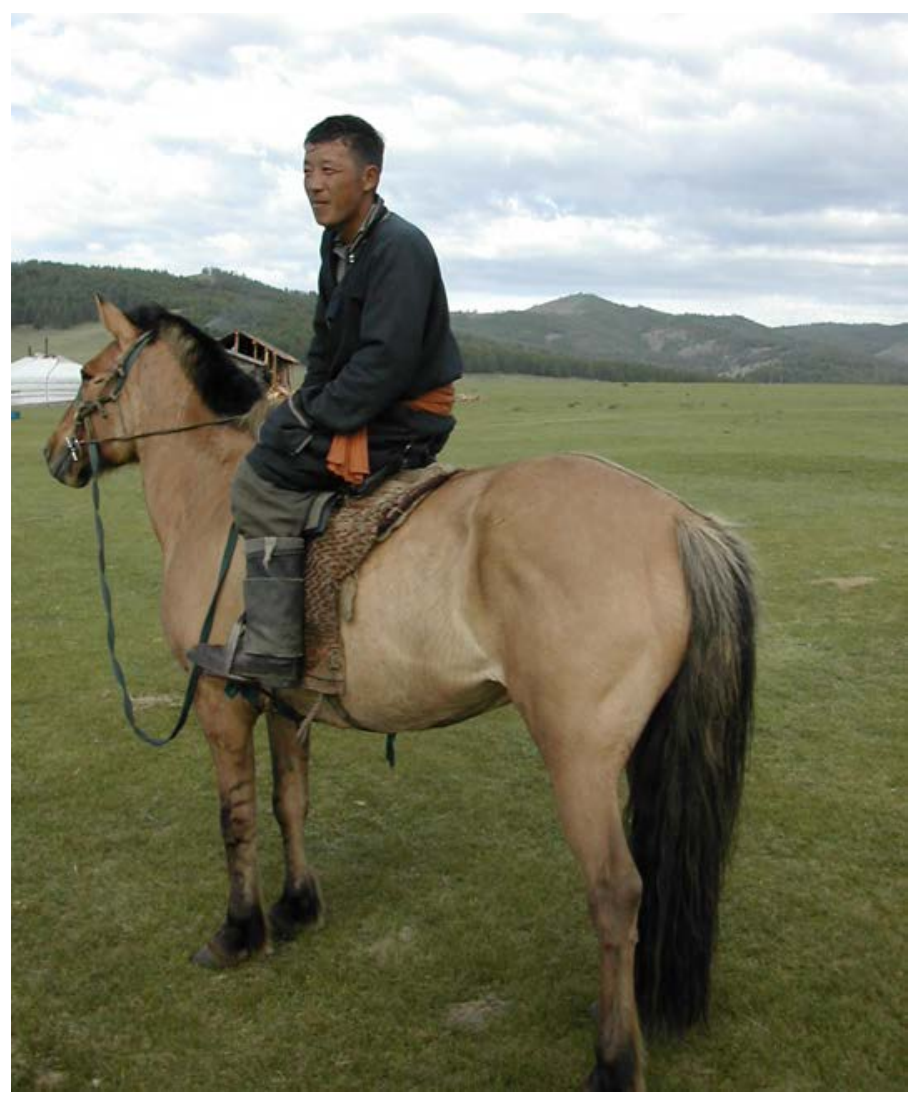

Figure 13.5: Mongolian herder with Mongolian horse, note the coat colour, eel-stripe down the back and stripes on the legs, Bugat Province, 2005. 


\section{Recent evidence from DNA analysis on the domestic and the wild horse}

From the genetic evidence, it is an unlikely scenario that horse domestication sprang up in just one location, but very likely that it occurred in a number of different geographical locations and that wild horses were repeatedly integrated within the domestic sphere even up until recent history when the last wild herds disappeared. To take a parallel hominid example, research on the Neanderthal genome found that Neanderthals have contributed toward the present day genetic ancestry of most humans beyond Africa (Green et al., 2010). Through studies into DNA, scientific ideas of what makes up a species, including humans and domestic animals, are rapidly changing.

Prior to modern day genetics it was thought that Equus przewalskii might represent the original wild ancestral stock from which all domestic horses stem. Through more recent DNA analysis it is now clear that they diverged as a distinct population before horses began to co-exist with humans (Ishida et al., 1995; Wallner et al., 2003). Early studies of their genetics indicate that takhi have a different number of chromosomes $(2 \mathrm{~N}=66)$ in comparison to domestic horses $(2 \mathrm{~N}=64)$ (Ryder, 1994), the difference being due to a simple Robertsonian translocation. They can readily interbreed and produce fertile offspring, whereas in other members of the genus Equus there is far greater chromosomal variation and the hybrid offspring are often infertile (for example, donkeys and horses produce infertile mules).

A large number of mares have contributed to a great variation of mitochondrial DNA in horses, indicating an 'extensive utilization and taming of wild horses' (Vila et al., 2001: 474). Jansen and others concluded perhaps more than 77 successfully breeding mares contributed to the domestic horse, leading them to suggest that 'the horse has been domesticated on numerous independent occasions' (2002: 531). Lindgren and others found that 'the maternal gene pool may have been diversified by the capture of only wild females from local populations (while backcrosses with wild stallions were prevented)' (2004: 335). Cieslak and others (2010) also found multiple introgressions of females adding to the genetic diversity, particularly from the Iron Age onwards. In the instance of Mongolia, this would have meant that once the captured takhi foals became adults, herders bred from takhi females with their Mongolian horse stallion.

Many genetic studies on the horse have focused specifically on the difference between the takhi and the domestic horse but the findings are controversial. Part of the lack of clarity surrounding the results of these analyses is that more than one domestic mare was interbred with takhi while in captivity (see Bökönyi, 1974; Mohr, 1971). This fact has been taken into consideration within 
genetic analyses (see for example, Oakenfull et al., 2000) but little consideration has been given to the likelihood of hybridisation with takhi occurring within the domestic horse population before the takhi disappeared from the grasslandsteppe.

It is interesting that as early as 1995, Ishida and others had tentatively suggested that some gene flow occurred between the ancestral populations of the Przewalski wild horse and the Mongolian native horse. Since then a number of authors have found that there is substantial overlap in terms of their mitochondrial DNA, or the maternal line (see for example, Myka et al., 2003; Vila et al., 2001). Analysis of the nucleotide sequence diversity along the $\mathrm{Y}$ chromosome, or male line, has revealed that the takhi is distinct from the domestic horse, suggesting that incorporation of takhi genes into the Mongolian horse population was by mares, not stallions (Wallner et al., 2003; Lindgren et al., 2004). This could be explained by the Mongolian herding practice of castrating most male horses in their second year, so that they remain tame and easy to handle. The males could have been kept for riding and racing purposes. Only the female takhi would have become reproductive adults and mated with the domestic Mongolian stallion within the herd, producing fertile hybrid offspring. By 2009, Lau and others felt able to state with more certainty that there was a constant flow of female mediated genetic information between takhi and domestic horses, and used the term 'unidirectional hybridisation' to describe interbreeding between takhi and domestic horses.

Mongolian horses show the largest amount of genetic diversity in comparison with other Asian and European horse breeds (Ishida et al., 1995; Tozaki et al., 2003). This diversity means that closely related Japanese and Korean horse breeds are derived from Mongolian horses. The Norwegian Fjord horse resembles the takhi in many physical features (Groves, pers. comm.). Bjørnstad and others suggested a close genetic relationship between the Mongolian and Norwegian horse. They concluded that the 'Mongolian horse has had a major impact on a wide range of breeds, and that Central Asia could have been a centre of dispersal of horses through trading and human migration' (2003: 57). Dispersal of Mongolian horses as far as Western Europe would have occurred particularly during the time of the Mongol Empire when the Khans ruled the largest empire in history (Morgan, 1986). It is, therefore, important to retain this genetic diversity and a robust population of Mongolian horses. The Mongolian horse is unique, as representatives of ancient ancestral stock, and should be valued for its role, not only as a partner in the unprecedented migration during the Khan Empire, but in providing a valuable contribution to the genetics of horse breeds across Eurasia today (see Figure 13.6). 


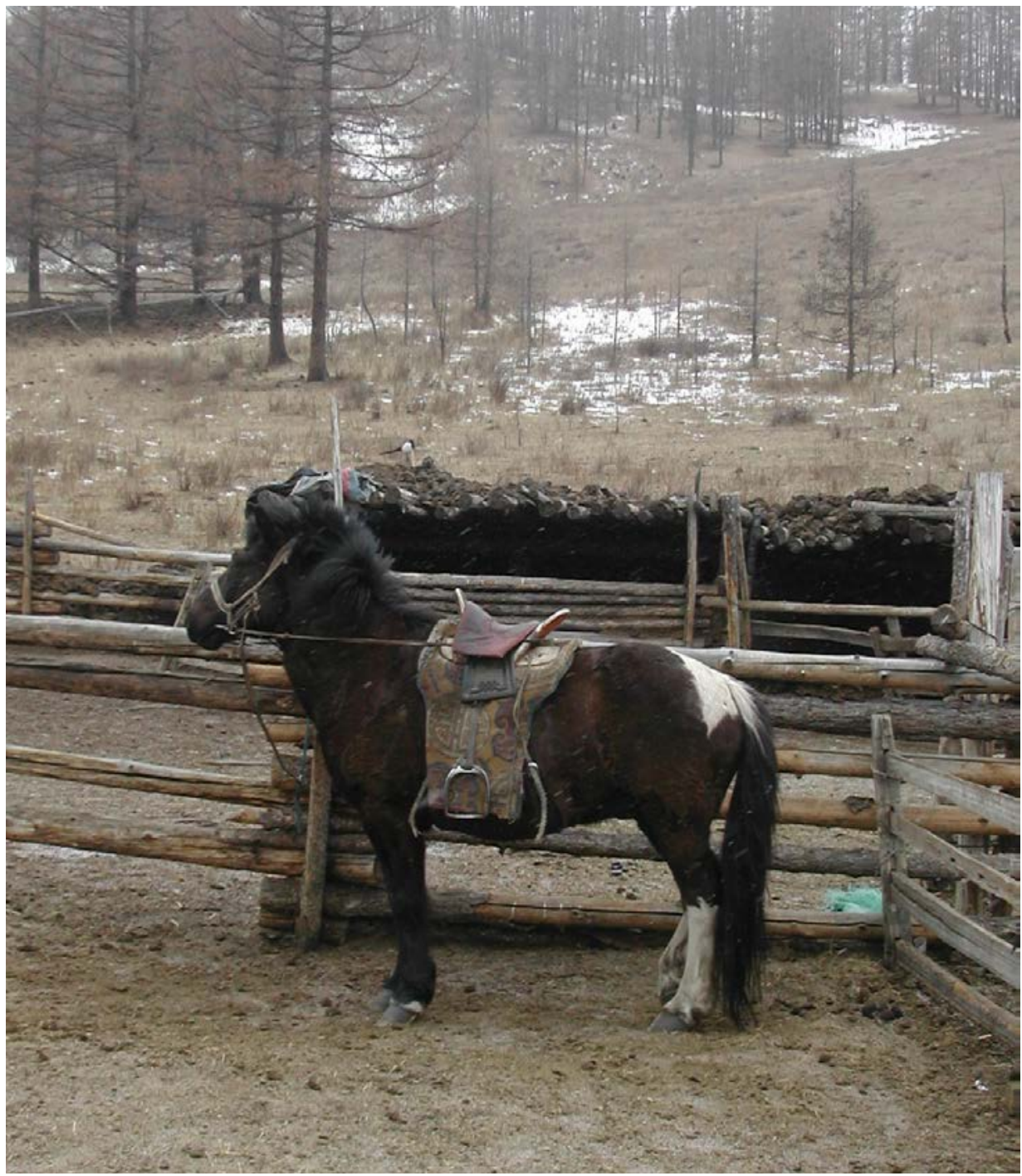

Figure 13.6: A saddled piebald (kharlag) Mongolian horse, Arkhangai Province, 2005.

Source: Photograph by Natasha Fijn.

\section{Conclusion}

The relationship between Mongolian herders and the Mongolian horse is unique. Through Mongolian herders allowing the horse greater agency, in allowing them to behave and live within a social structure that they would adopt of their own 
volition, they are allowing horses greater autonomy. Natural selection can still occur to a notable degree in the Mongolian horse and the population is likely to be more resilient as a result. Mongolian horses have retained their anti-predator behaviour against wolves and an ability to forage on the grassland throughout the seasons, without the dependence found in Euro-American breeds.

To Mongolian herders, the difference between a 'domestic' and a 'wild' animal is not considered so much according to a physiological or morphological condition but relates more to behavioural disposition: domestic animals are tame and associate with humans and the herding encampment, while those that are wild are afraid and choose not to live with humans. King and Gurnell describe how before the takhi were reintroduced into reserves, 'there was no [Western] knowledge about the ecology of takhi in the wild before they became extinct, and so it was not clear how the released animals would cope in their new surroundings' (2005: 278). It would have come as no surprise to Mongolian herders, however, that the reintroduced takhi would be capable of surviving on the grassland steppe, as their horse herds have been successfully doing so for tens of hundreds, if not thousands of years. It took me some months to adjust to life in Mongolia, the takhi also took time to adjust after their forebears had spent 13 generations in captivity in Europe. The takhi population is now thriving and have adapted smoothly to living on the grassland steppe, ${ }^{8}$ just as many horses throughout the world have adjusted to become 'feral' and no longer require an association with humans to survive. Instead of viewing domestic and wild as a hyper-separated dichotomy, these different states should be thought of as being more fluid, where there can be considerable cross-over, or interbreeding, between the two.

Colin Groves is the world expert on the morphology and taxonomy of Equus przewalskii, or the takhi. It should be noted that he encourages those he has mentored to explore different avenues and he readily embraces interdisciplinary research. This has meant that I have not been constrained in my exploration of the relationship of the takhi and the Mongolian horse, through not only the taxonomic and morphological analysis, but also my ethnographic findings from Mongolia, previous historical accounts and the current wealth of scientific literature on the genetics of the horse. This has led me to conclude, in agreement with Colin Groves' previous findings, that the takhi are morphologically and genetically distinct from other horses and merit our conservation. Any conservation project with the goal of reintroducing 'wild' takhi herds back into Mongolia should seriously take into account Mongolian herding knowledge and expertise.

8 Reintroductions to Hustai Nuruu National Park began in 1992. By 2000 the population at this reserve alone consisted of 120 horses (King, 2002). 
Prior to the capture and confinement of the entire takhi population in zoos across the globe, it is highly likely that there was integration of individual takhi within Mongolian horse herds and this would have inevitably influenced the diverse genetic makeup of the native Mongolian horse. This evidence should help to dispel the popular portrayal of the 'origin myth' in relation to animal domestication: the view that the domestication of the horse was a singular instance, occurring at some stage during the Neolithic, and that the scientific goal should be to pinpoint this particular point in time with a specific date. The process of the domestication of the horse from the 'wild' is not a dichotomous one, where a binary line is crossed, but is a fluid, adaptable and ongoing process that still occurs into the present day.

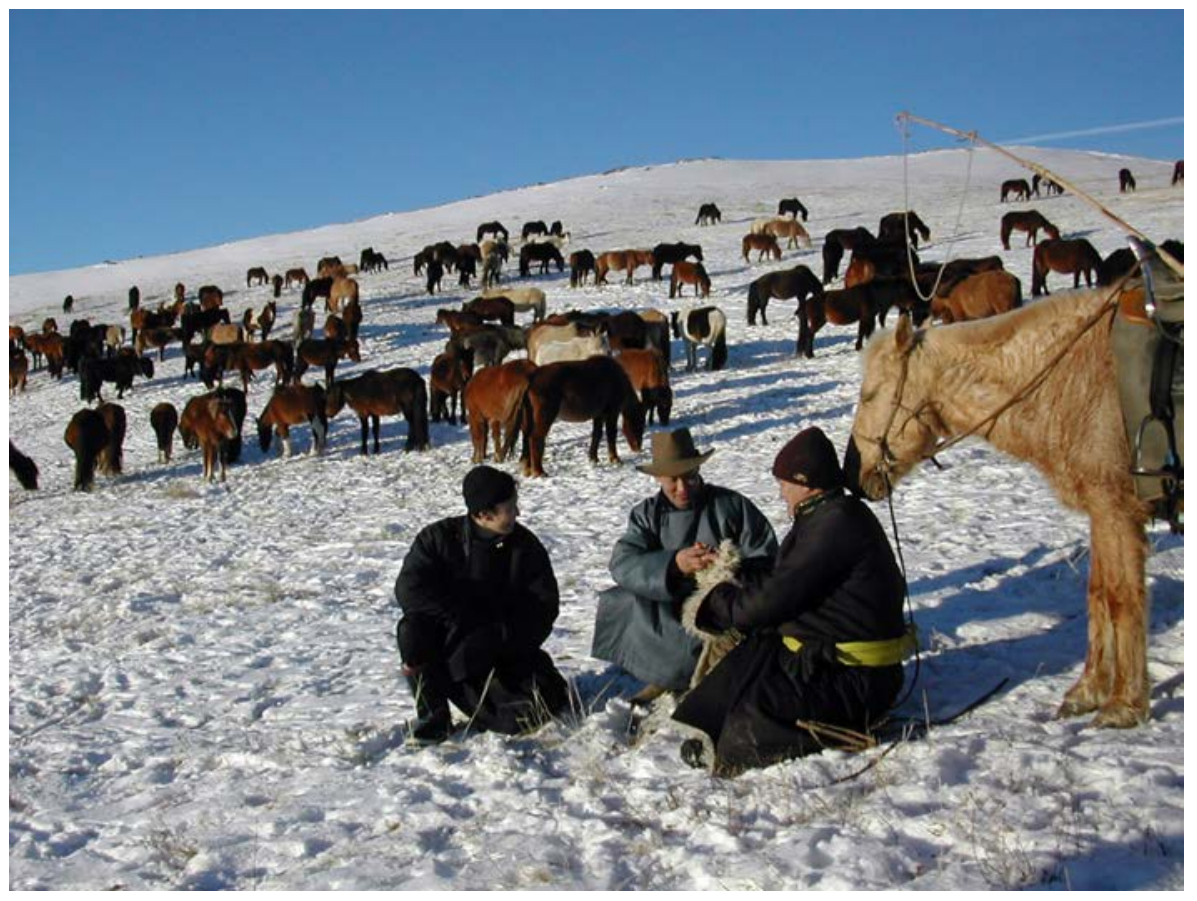

Figure 13.7: Mongolians greeting by passing snuff. Note the colour diversity within one large herd of Mongolian horses.

Source: Photograph by Natasha Fijn.

\section{References}

Bedunah DJ, Schmidt SM. 2000. Rangelands of Gobi Gurvan Saikhan National Conservation Park, Mongolia. Rangelands 22(4):18-24. 
Taxonomic Tapestries

Bjørnstad G, Nilsen NØ, Røed K. 2003. Genetic relationship between Mongolian and Norwegian horses? Anim Genet 34:55-58.

Bökönyi S. 1974. The Przevalsky horse. London: Souvenir Press.

Bouman I, Bouman J. 1994. The history of Przewalski's horse. In: Boyd L, Houpt KA, editors. Przewalski's horse: The history and biology of an endangered species. New York: SUNY. pp. 5-38.

Boyd L, Houpt KA. 1994. Przewalski's horse: The history and biology of an endangered species. New York: SUNY.

Cassidy R. 2002. The sport of kings: Kinship, class and thoroughbred breeding in Newmarket. Cambridge: Cambridge University Press.

Cieslak M, Pruvost M, Benecke N, Hofreiter M et al. 2010. Origin and history of mitochondrial DNA lineages in domestic horses. PLOS ONE 5(12): e15311. doi:10.1371/journal.pone.0015311.

Clutton-Brock J. 2012. Animals as domesticates: A world view through history. Michigan: Michigan State University Press.

Fijn N. 2011. Living with herds: Human-animal coexistence in Mongolia. Cambridge, New York and Melbourne: Cambridge University Press.

Green RE, Krause J, Briggs AW, Maricic T et al. 2010. A draft sequence of the Neandertal genome. Nature 328:710-722.

Groves CP. 1986. The taxonomy, distribution and adaptations of recent equids. In: Meadow RH, Uerpmann HP, editors. Equids in the Ancient World. Wiesbaden: Ludwig Reichert Verlag. pp. 11-65.

Groves CP. 1994. Morphology, habitat and taxonomy. In: Boyd L, Houpt KA, editors. Przewalski's horse: The history and biology of an endangered species. New York: SUNY. pp. 39-60.

Groves C, Grubb P. 2011. Ungulate taxonomy. Baltimore: Johns Hopkins University Press.

Groves C, Willoughby DP. 1981. Studies on the taxonomy and phylogeny of the genus Equus 1. Subgeneric classification of a recent species. Mammalia 45(3):321-354.

Hovens JPM, Tungalaktuja K. 2005. Seasonal fluctuations in the wolf diet in the Hustai National Park (Mongolia). Mammal Biol 70(4):210-217. 
Ishida N, Oyunsuren T, Mashima S, Mukoyama H, Saitou N. 1995. Mitochondrial DNA sequences of various species of the genus Equus with special reference to the phyogenetic relationship between Przewalskii's wild horse and domestic horse. J Mol Evol 41:180-188.

Jansen T, Forster P, Levine MA, Oelke H et al. 2002. Mitochondrial DNA and the origins of the domestic horse. PNAS 99(16):10905-10910.

Kaczensky N, Enkhsaihan O, Ganbaatar O, Walzer C. 2007. Identification of herder-wild equid conflicts in the Great Gobi B strictly protected area in NSW. Erforsch biol Ress Mongolei 10:1-18.

Kaszab Z. 1966. New sightings of Przewalski Horses. Oryx 8(6):345-347.

King SRB. 2002. Home range and habitat use of free-ranging Przewalski horses at Hustai National Park, Mongolia. Appl Anim Behav Sci 78:103-113.

King SRB, Gurnell J. 2005. Habitat use and spatial dynamics of takhi introduced to Hustai National Park, Mongolia. Biol Conserv 124:277-290.

King SRB, Gurnell J. 2007. Scent-marking behaviour by stallions: An assessment of function in a reintroduced population of Przewalski horses (Equus ferus przewalskii). J Zool 272:30-36.

Lau AN, Peng L, Goto H, Chemnick L et al. 2009. Horse domestication and conservation genetics of Przewalski's horse inferred from sex chromosomal and autosomal sequences. Mol Biol Evol 26(1):199-208.

Lindgren G, Backström N, Swinburne J, Hellborg L et al. 2004. Limited number of patrilines in horse domestication. Nat Genet 36(4):335-336.

Linklater WL. 2000. Adaptive explanation in socio-ecology: Lessons from the Equidae. Biol Rev 75:1-20.

Lusis JA. 1943. Striping patterns in domestic horses. Genetica 23(1):31-62.

Mallon DP, Jiang Z. 2009. Grazers on the plains: Challenges and prospects for large herbivores in Central Asia. J Appl Ecol 46:516-519.

Mohr E. 1971. The Asiatic wild horse. London: J. A. Allen \& Co.

Morgan D. 1986. The Mongols. Oxford: Basil Blackwell.

Myka JL, Lear TL, Houck ML, Ryder OA, Bailey E. 2003. Fish analysis comparing genome organization in the domestic horse (Equus caballus) and the Mongolian wild horse (E. przewalskii). Cytogenet Genome Res 102:222225 . 
Taxonomic Tapestries

Nalle D. 2000. Tournament of shadows: The great game and the race for empire in Central Asia. Middle East Policy 7(3):199-200.

Oakenfull EA, Ryder OA. 1998. Mitochondrial control region and 12S rRNA variation in Przewalski's horse (Equus przewalskii). Anim Genet 29(6):456459.

Plumwood V. 2012. The eye of the crocodile. Canberra: ANU E Press.

Ryder OA. 1994. Genetic studies of Przewalski's horses and their impact on conservation. In: Boyd L, Houpt KA, editors. Przewalski's horse: The history and biology of an endangered species. New York: SUNY. pp. 75-92.

Pruvost M, Bellone R, Benecke N, Sandoval-Castellanos E et al. 2011. Genotypes of predomestic horses match phenotypes painted in Paleolithic works of cave art. PNAS 108(46):18626-18630.

Tozaki T, Takezaki N, Hasegawa N, Ishida M et al. 2003. Microsatellite variation in Japanese and Asian horses and their phylogenetic relationship using a European horse outgroup. J Hered 94(5):374-380.

van Dierendonck MC, Bandi N, Batdorj D, Dügerlham S, Munkhtsog B. 1996. Behavioural observations of reintroduced Takhi or Przewalski horses (Equus ferus przewalskii) in Mongolia. Appl Anim Behav Sci 50:95-114.

van Dierendonck MC, Goodwin D. 2005. Social contact in horses: Implications for human-horse interactions. In: de Jong $\mathrm{FH}$, van den Bos $\mathrm{R}$, editors. The human-animal relationship. Assen, The Netherlands: Van Gorcum. pp. 6581 .

van Dierendonck MC, Wallis de Vries MF. 1996. Ungulate reintroductions: Experiences with the takhi or Przewalski Horse (Equus ferus przewalskii) in Mongolia. Conserv Biol 10(3):728-740.

Vila C, Leonard JA, Götherström A, Marklund S et al. 2001. Widespread origins of domestic horse lineages. Science 291(5503):474-477.

Wallner B, Brem G, Müller M, Achmann R. 2003. Fixed nucleotide differences on the $\mathrm{Y}$ chromosome indicate clear divergence between Equus przewalskii and Equus caballus. Anim Genet 34:453-456. 
This text is taken from Taxonomic Tapestries: The Threads of Evolutionary, Behavioural and Conservation Research, edited by Alison M Behie and Marc F Oxenham, published 2015 by ANU Press, The Australian National University, Canberra, Australia. 